\title{
Portrayal of Oedipal Desires in Vijay Tendulkar's The Cyclist
}

Dr. Shivali Bansal

Lecturer, Education Department, Uttar Pradesh, India.

\begin{abstract}
The Oedipus Complex is a term used by Sigmund Freud in his theory of psychosexual stages of development to describe a boy's feelings of sexual desire for his mother and jealousy and anger towards his father for the possession of his mother. The child considers his father as a rival for her attention and affection. The concept of the Oedipus Complex was first discovered by Freud during his self-analysis in 1897 and presented in his publications of the next decade. Oedipus complex is the greatest, the most crucial sexual conflict in Freud's model of psychosexual development. The great master psychologist Sigmund Freud praised literary artists for their accurate observations of the subtlety and complexity of the human mind. Vijay Tendulkar is a leading Indian playwright who shows unusual insight into the complexities of human psyche and lays bare various psychological factors, imparting to his portrayals of characters an element of human authenticity. This phenomenon of Oedipus Complex is interwoven into the texture of the play The Cyclist written by Vijay Tendulkar.
\end{abstract}

Keywords-Existentialism, Mermaid, Oedipus Complex, Psychosexual development, The Cyclist.

The term Oedipus Complex denotes "the medley of strivings, feelings and unconscious ideas grouped round the individual's wishes to possess sexually the parent of the opposite sex and to get rid of the parent of the same sex." (Fenichel: 1931: 412-413)

For Freud "the Oedipus complex is a universal, psychological phenomenon innate (phylogenetic) to human beings and the cause of much unconscious guilt." (Oedipus Complex: http://en.wikipedia.org) His basic idea is that young children have sexual drives and ideas which affect their individual psyche. For Freud, the personality development of a child passes through five stages - (1) The Oral Stage, (2) The Anal Stage, (3) the Phallic Stage, (4) The Latency Period, (5) The Genital Stage. In the Oral stage which begins at birth and lasts approximately one or one and a half year, the oral cavity is the primary focus of libidinal energy. The child's focus of pleasure in the Anal stage is centered on the retention or expulsion of the feces. The child has to learn to control through the training given by parents. It represents "a classic conflict between the id, which derives pleasure from the expulsion of bodily wastes and the ego and super-ego, which represent the practical and societal pressures to control the bodily functions." (Stevenson: 'Freud's Psychosexual Stages of Development' : www.victorianweb.org) The resolution of the Anal stage, proper toilet training, permanently affects the individual propensities to possession and attitudes towards authority. In the third stage which is called the Phallic stage, a boy's decisive psychosexual experience is the Oedipus Complex - the son-father competition for the possession of the mother. In this stage, the child's erogenous zone switches to the genital region. Children become aware of their bodies, the bodies of the other children, and the bodies of their parents. They learn the anatomic differences between 'male' and 'female' and the gender difference between 'boy' and ' $g$ irl' and it alters the dynamics of the parent and child relationship. The boy's libido or sexual desire is directed upon his mother and he develops jealousy and emotional rivalry against his father because it is the father who sleeps with his mother. Moreover, to facilitate union with mother, the boy's id wants to kill $h$ is father but the ego knows that father is stronger than him and may punish him by castrating him. This castration anxiety or castration complex is an irrational, subconscious manifestation of the infantile id. The conflict is resolved by "relinquishing his desire for the mother (adopting an incest taboo), as he becomes the father mentally, that is, he identifies with the imagined punitive father and internalizes the castration threats as a moral conscience." (Le Vine: 2010: 120) By identifying with the parent of the same-sex, the boy diminishes his castration anxiety, because his likeness to father protects him from father's wrath in their maternal rivalry. Thus the satisfactory parental handling and resolution of the Oedipus complex are very important in developing the male infantile super-ego. Hence the man who is fixated in the Oedipal stage of their psychosexual 
development may be considered mother-fixated as revealed when the mate (sexual partner) resembles the mother.

The resolution of the phallic stage leads to the latency period in which the sexual drive lies dormant. In this period which continues from the age of six years to puberty, children pour their repressed libidinal energy into asexual pursuits such as intellectual activities, athletics and social interaction. They develop mostly same-sex friendship during this period. In the Genital stage, the final stage of psychosexual development, which begins during puberty but lasts throughout the rest of a person's life, the individual develops a strong sexual interest in the opposite sex. An attempt has been made in this paper to critically analyze how this phenomenon of Oedipus complex comes to the surface in the play The Cyclist.

Vijay Dhondopant Tendulkar, one of the four pillars of modern Indian theatre (the other three being Badal Sircar, Girish Karnad and Mohan Rakesh) is a prolific writer whose plays made a clear break from the sententious, sentimental and melodramatic plays that dominated the mainstream theatre of the time. In his plays he is concerned with man's fight for survival, the varied moralities by which people live, the social position of women, the covert or overt violence in human beings and the eternal chain of victim-victimizer syndrome. He presents these concerns in different forms in different plays with humanistic concerns always reigning supreme. The Cyclist, intended to be his last play, translated by Balwant Bhaneja, is different from Tendulkar's other works. In this play, he made a bold experiment, writing "an allegory about the journey of life".

The play describes a young man who sets out on a journey astride his wheelless bicycle. There is no specific geographical location in which the play is set; the play describes only a place from where the cyclist is trying to get away. As the journey progresses, the cyclist encounters various types of persons and hazards - natural, supernatural and human as well. As he rings the bell of his cycle, he is threatened by a man whom he addresses as his neighbour Jogeshtey Uncle. Right in the beginning of his journey, he is faced with the problem of choice as he reaches a place where three roads meet. When threatened by a passer-by, the cyclist moves ahead on a road by chance, he finds that he is "on the road, which instead is going back into the city." (Tendulkar: 2006: 14) Then he comes across a sage who "about turns" him and he resumes his journey. (Tendulkar: 2006: 15) Along his journey, the Main Character is "waylaid by hoodlums, threatened with legal actions by the lords of heaven and earth, sized up and rejected by a picky lion, stalked by a lonely ghost..." (Bryan: 'The Cyclist': www.timeoutbengaluru.net) Then he is taken over by sudden rain. Being drenched with rain, he stops to get his clothes dried. It is here that he meets a sweet-talking mermaid who claims to have swallowed his clothes. It is his encounter with the mermaid which abruptly ends his journey and he is once again scolded for making a noise by the same man whom he called Jogeshtey Uncle before. As he complains against his neighbour, he looks younger and younger and folds himself in a foetal position round his bicycle. The play The Cyclist is an allegory representing the idea of the journey of life. This play is an exploration of the psyche of a cyclist whose journey on a wheelless bicycle becomes an occasion for the exploration of the hidden mystery of universe and human life. It is significant to note that the cyclist is simply called the Main Character. In fact, Tendulkar chooses to leave him nameless in order to suggest that "he bears all our names." (Bryan: 'The Cyclist': www.timeoutbengaluru.net) Besides it, all the other characters in the play have been consciously given symbolic names or titles as $\mathrm{Ma}, \mathrm{Pa}$, Lion, Ghost, Lord of Heaven and Earth, Dakoo El Bandito etc. In order to indicate a universal human experience and "to transcend boundaries of culture and geography", Tendulkar has reduced references to particular locality or culture. (Savitha: Deccan Herald: 2006)

The journey of the cyclist can be interpreted at many levels ranging from the physical to the metaphysical. In this connection Balwant Bhaneja remarks: "The Cyclist is not about one but three journeys: Apart from being a journey in geographical terms, it is a psychological exploration of the protagonist's mind and offers insight into the historical significance of the bicycle." (Bhaneja: 2006: viii) In analyzing the consciousness of an individual, the play contains some veiled references to the phenomenon of Oedipus complex.

In the beginning of the play the cyclist is seen as ready to embark on a journey with all the initial paraphernalia needed for it. In his in itial dialogue with self, the Main Character narrates the protection and care given to him by his parents in his childhood. He informs: "I have never been out. Amma and Pa never let me go. The only child! My older brother lived only two months. Then died. Did not let me go. That's why they said, 'There's everything in this house - Why go out and waste yourself? They got me a bicycle. I'd wheel it around, everywhere but only inside the house." (Tendulkar: 2006: 7) He gives some hints of his attachment to his mother and his conflict with his father in his childhood: " $\mathrm{Pa}$, a real gent. Once in a 
while he would slap me across the face. Just a habit. A mma totally safe. Never hit me. If I made a mistake, she'd cry instead. Then I'd say, 'Ma, I am sorry. I won't do it aga in.' She was the one who taught me to say that." (Tendulkar: 2006: 7) In his childhood, he was kept confined to the house, was allowed to move around only within the parameters of his home. He would dream of going outside but finds himself powerless in front of parental authority. He visualizes his dream: "I cross the door. I am on the landing, near the stairs. I ride down the stairs. Then, I can see the road outside our front door. And in the distance, the bridge across the rail tracks, and running along the bridge, the highway! There, I am standing proud over my bicycle. Dreaming so, I grew older. In fact, I am gutsy. But it takes so long to convince Amma and Pa to let me go." (Tendulkar: 2006: 7-8) It is because of his affection for his mother and fear of the father that he dithers to leave his parents but the alluring call of his dreams which corresponds to a child's need for socialization compels him to start his journey. The secluded life given to the Main Character in his childhood signifies the lack of proper parental handling of his psychosexual development. He feels suffocated in the narrow, circumscribed atmosphere of the home. So he bids farewell to his parents with the words: "I'm in your debt forever. For all you've done, I'll never repay enough. But the time's come now to get off the potty and smell the world. (Kneeling, formal) Blessed mother, bid me farewell! And thou, dear Dad, wish me good speed!" (Tendulkar: 2006: 9) The absence of the interaction with the world around him has left him immature and naïve. Arundhati Banerjee rightly remarks that "the play appears to be an exploration of the individual psyche that has remained completely immature and innocent. Tendulkar explains that he has come across people who survived in narrow, circumscribed lives wrapped in cocoons - cocoons that they had woven around themselves to create a total detachment from the harshness of life. He also admits that during childhood and early youth, he had possessed a similar innocence and that there is something of that self in the character he had created." (Banerjee: 'A Vintage Year') His naiveté and innocence is revealed in the way he deals with the crowd, the passerby and the sage. As he moves on his journey with nervousness and excitement, he encounters many obstacles which are surmounted by him, sometimes with the help of someone, sometimes with the aid of luck or his own practical wit and intelligence. It makes the cyclist more confident and resolute to continue his journey with renewed zest and vigour. Whenever he is entangled in a problem, he recalls the advice given to him by $\mathrm{Pa}$ which shows his growing identification with his father. When the Main Character comes across a ghost, he finds himself unable to cope with it and seeks the counsel of his father. However, the solution that $\mathrm{Pa}$ suggests is "the mockery of entire civilization and it reflects on the condition of post-modern society that is subjected to impotency and nothingness." (Agrawal: 2010: 212) Pa finally advises: "In this life, the worst possible tragedies happen - individually, nationally, globally these occur, and their solutions: DO NOTHING. Every problem ultimately resolves itself." (Tendulkar: 2006: 31) With the counsel of Pa he ultimately gets success in saving himself from the ghost, the inhabitant of darkness, who withdraws from the scene with the clicking of the dawn. The cyclist resumes his journey on a new day with fresh ardour and excitement.

It appears that the journey of the cyclist begins in the latency period in which there is an inner urge to have knowledge of the world around oneself and in which a man's libidinal desires lie in a dormant state and his attention is directed towards same-sex peers. In the very beginning of the play, when the Main Character states his dream of watching "unexplored places - mountains, deserts, water" , of having "new experiences" and of making "new friends", he expresses his unwillingness to have girl friends: "Have 'g irl' friends! No, no girlfriends we don't get along." (Tendulkar Tendulkar: 2006: 7) The beginning of the new day which infuses the cyclist with renewed vigour and confidence, signifies his transformation into a full fledged human being of the male sex. In fact, the bald patch on the head of the cyclist, which viewers see in the last scene, indicates the adulthood of the cyclist, the protagonist. Sexual attraction for the opposite sex is bound to come in a man's process of development and one cannot escape it. For the cyclist, it comes in the form of the Mermaid. When the cyclist is drenched by sudden rain, he finds it impossible to move any further and takes off his clothes and puts them on a rope to let them dry. It is at this time when he hears a female voice which calls him 'Sindbaad'. This voice claims to like him. The frightened cyclist wraps himself in a torn map and once again cries for the help of $\mathrm{Pa}$. The way $\mathrm{Pa}$ appears in his consciousness only indicates his identification with his father. This identification is reinforced by the seminakedness of the father who appears shirtless and hatless like his son who tries hard to hide his shame through a tattered map. Pa reiterates his clichéd advice: "Let her come. As I always say 'eyes closed, mountain gone'. If you don't see her, she doesn't exist." (Tendulkar: 2006: 36) 
Despite the cyclist's attempts to evade the problem by following Pa's counsel, he is forced to face this phenomenon. The mermaid bodily appears in front of his eyes in order to wake him up from his illusion of having closed his eyes. She introduces herself as Princess Madalsa. She appears to be an enchantress, a figure coming out from a medieval romance. She informs: "I'm under a curse... the curse of an evil king. I am a princess. I can sing, dance, speak 53 languages. You have won my heart, Sindbaad!" She swallows the clothes of the cyclist in order to prevent him from running away from her. Her swallowing of the clothes of the cyclist amounts to his seduction by her. She dreamily says: "I will guard them for nine months in my wo mb...your clothes. Then I'll give birth to a lovely child. A child in your clothes, handsome as you. He will call you Pa, Pa, Papa and me Ma, ma." (Tendulkar: 2006: 38) Apart from being a beloved, she now becomes a mother figure. The Main Character too says: "Please go away! What's happening? Mother, lady, you swallowed my clothes... what right did you have to do that?" (Tendulkar: 2006: 39) She desires to promote the cyclist to the status of fatherhood but he appears to be reluctant and continually demands his clothes back.

In fact, the Mermaid is a symbolic figure. She represents the projection of the oedipal desires latent in the psyche of the cyclist. Despite his reluctance, the cyclist's oedipal desires are resurfaced in the form of the Mermaid. Balwant Bhaneja rightly remarks: "Mermaid's seduction of the cyclist is that of Oedipus, a composite of mother, girlfriend and enchantress." (Bhaneja: 'Introduction':2006: $\mathrm{x})$ The process of sexual encounter and procreation is a necessary stage of human life and development. It is here that the play The Cyclist transcends the story of single individual and becomes symbolic of any man's journey through life. The obstacles, sufferings, monotony, joys - all seem to reflect a modern man's voyage through life. If the cyclist is representative of every man, the Mermaid is the incarnation of everywo man whose quest is for a mate who is a composite of a lover, father figure and romantic adventurer. It is the cyclist's entanglement with the Mermaid that abruptly ends his metaphysical journey, wakes him up from his dream and brings him back to the reality around him. His meeting with the Mermaid signifies his desire to connect to his mother again and to go back to his roots. It can be done only by reentering into the wo mb and so he comes to the fetal position. Through this journey, he wants "to solve his existential riddle - what is the meaning of one's life, between one's birth and death. Unable to resolve the issues of killing, greed, destruction of environment etc. surrounding him, the mermaid provides him an imag inary escape to return to his mother's fold, as an infant in conception in mother's embryo." (Bhaneja: In an email conversation with the researcher) The realization that it was not a successful journey and his curling up in a wo mb-like position indicates his desire to relive his life. So in a sense, the mermaid signifies "the death and the beginning of life." (Jeshi: Metro Plus Bangalore: 2009)

Human psyche enjoys its own autonomy of self whose fluid states reject the conformity with the accepted patterns of tradition and culture. It is a difficult task to represent the labyrinthic depths of human mind in a literary form especially in drama. The Cyclist is a glowing testimony of Tendulkar's art of exploring the finer and subtle nuances of human psyche and giving expression to them.

\section{REFERENCES}

[1] Agrawal, Beena, 'The Cyclist: Probing into the Journey of Life', Dramatic World of Vijay Tendulkar: Explorations and Experimentations (Jaipur: Aadi Publications: 2010)

[2] Banerjee, Arundhati, 'A Vintage Year' : A part of the clippings collected on Vijay Tendulkar by Sangeet Natak Akademi.

[3] Bhaneja, Balwant, 'Introduction', Two Plays by Vijay Tendiulkar: The Cyclist, His Fifth Woman ( New Delhi: Oxford University Press: 2006).

[4] Bhaneja, Balwant: In an email conversation with the researcher with the email id: billbhaneja@rogers.com.

[5] Bryan, Richard, 'The Cyclist ': http://www.timeoutbengaluru.net/ theatre/theatre_details.asp? $\operatorname{code}=233 \&$ source $=1$.

[6] Fenichel, Otto, 'Specific Forms of Oedipus Complex', The International Journal of Psychoanalysis, 12, 1931, retrieved from: http://www.pebweb.org/document.php?id=ijp.012.0412a .

[7] Freud, Sigmund, 'The Material and Sources of Dreams', The Interpretation of Dreams (New York: Avon books: 2006).

[8] Levine, Robert Alan, 'Psychological Anthropology : A Reader on Self in Culture', Vol.13 of Blackwell Anthologies in Social and Cultural Anthropology (John Wiley and Sons:2010).

[9] Oedipus Complex: http://en.wikipedia.org/wiki/Oedipus_complex.

[10] Oedipus Complex: http://www.miriamwebster.com/ concise/ oedipus complex . 
[11] Parth Sarathi, Kumar: 'The Cyclist: An Ontological quest of an Urban Individual': retrieved from:

http://www.anvikshikijournal.co m/viewpaper.asp x?pc ode $=32 \mathrm{f} 346 \mathrm{c} 4-9233-467 \mathrm{~b}-884 \mathrm{f}-86220 \mathrm{dd} 11885$.

[12] Savitha, G. R. K., 'Of Gripping Scripts and Plays', Deccan Herald, Dec. 10, 2006.

[13] Stevenson, David B., 'Freud's Psychosexual Stages of Development':

http://www.victorianweb.org/science/freud/develop.ht $\mathrm{ml}$.

[14] Tendulkar, Vijay, 'The Cyclist', trans. Balwant Bhaneja, The Cyclist and His Fifth Woman: Two Plays by Vijay Tendulkar (New Delhi: Oxford University Press: 2006). 